\title{
Falsification and the Role of the Theory of Mind in the Reduced Array Selection Task
}

M. Bucciarelli and P. N. Johnson-Laird

\section{(2) OpenEdition \\ 12 Journals}

Electronic version

URL: http://journals.openedition.org/cpl/174

DOI: $10.4000 / \mathrm{cpl} .174$

ISSN: $1379-6100$

Publisher

Centre PsyCLÉ

Printed version

Date of publication: 1 April 2001

\section{Electronic reference}

M. Bucciarelli and P. N. Johnson-Laird, «Falsification and the Role of the Theory of Mind in the

Reduced Array Selection Task », Current psychology letters [Online], 2001/1, 4 | 2001, Online since 05

September 2003, connection on 08 September 2020. URL : http://journals.openedition.org/cpl/174 ;

DOI : https://doi.org/10.4000/cpl.174

This text was automatically generated on 8 September 2020.

(C) All rights reserved 
Falsification and the Role of the Theory of Mind in the Reduced Array Selection Task

M. Bucciarelli and P. N. Johnson-Laird 